\title{
Effects of Bacteriophage Therapy on Host Immune Responses in Brucellosis Affected Cattle
}

\section{Anju Mohan and Hari Mohan Saxena*}

Department of Veterinary Microbiology, College of Veterinary Science, Guru Angad Dev Veterinary and Animal Sciences University, Ludhiana, India 141001.

*Corresponding Author: Hari Mohan Saxena, Department of Veterinary

Microbiology, College of Veterinary Science, Guru Angad Dev Veterinary and Animal Sciences University, Ludhiana, India .
Received: April 10, 2020

Published: May 28, 2020

(C) All rights are reserved by Anju Mohan and Hari Mohan Saxena.

\begin{abstract}
We studied the effect of phage therapy on immune responses in Brucellosis affected cattle. There was a very significant ( $\mathrm{p}<0.01$ ) increase in total serum proteins from $0 \mathrm{D}$ to $45 \mathrm{D}, 60 \mathrm{D}$ and $75 \mathrm{D}$ and from $30 \mathrm{D}$ to $45 \mathrm{D}$ and a decrease from 45D to $90 \mathrm{D}$, respectively. There was a significant $(\mathrm{p}<0.05)$ increase in total serum proteins from $0 \mathrm{D}$ to $30 \mathrm{D}$ and $90 \mathrm{D}$ and a decrease from 45D to 75D. Serum globulin level increased very significantly $(\mathrm{p}<0.01)$ from $0 \mathrm{D}$ to $45 \mathrm{D}$ and 60D. The increase in serum globulin level from 30D to 45D and decrease from 45D to 90D were significant $(\mathrm{p}<0.05)$. There was a very significant $(\mathrm{p}<0.01)$ rise in anti-Brucella antibody titers estimated by Standard Tube Agglutination Test (STAT titers) from 0D to 45D and 60D along with a significant ( $\mathrm{p}<0.05$ ) decline from 45D to 90D. There was a very significant ( $\mathrm{p}<0.01$ ) rise in MAT titers from 0D to 45D and 60D along with a decline from 45D to 90D. The rise in titer from $30 \mathrm{D}$ to $45 \mathrm{D}$ was significant $(\mathrm{p}<0.05$ ). There was a very significant $(\mathrm{p}<0.01$ ) rise in IHA titers from $0 \mathrm{D}$ to $45 \mathrm{D}$ and $60 \mathrm{D}$ and a significant $(\mathrm{p}<0.05)$ rise from $0 \mathrm{D}$ to $75 \mathrm{D}$. There was a very significant $(\mathrm{p}<0.01)$ decline in ELISA titers from 30D to 60D, $75 \mathrm{D}$ and $90 \mathrm{D}$, respectively. The decline in titers from $0 \mathrm{D}$ to $60 \mathrm{D}$ and $75 \mathrm{D}$ and from $45 \mathrm{D}$ to $60 \mathrm{D}$ and $75 \mathrm{D}$ was significant ( $\mathrm{p}<0.05$ ). There was a very significant $(\mathrm{p}<0.01)$ decrease in the levels of lymphocytes from $0 \mathrm{D}$ to $30 \mathrm{D}$ followed by increase from 30D to 45D, 60D and 75D. The increase from 30D to 90D was very significant ( $\mathrm{p}<0.01$ ). However, Levels of leukocytes, monocytes and neutrophils did not differ significantly among themselves during the period of 90 days after treatment with the phage.This suggests that phage therapy in Brucellosis stimulates immune responses in cattle initially which decline slowly after 45 days.
\end{abstract}

Keywords: Phage Therapy; Brucellosis;_Antibody Titers; Leukocytes; Lymphocytes; Neutrophils

\section{Introduction}

Brucellosis is a major bacterial zoonosis of global importance. About 500,000 cases of human brucellosis are estimated to occur worldwide every year.

Bovine brucellosis is endemic in all states of India. In India, the occurrence of brucellosis is to the extent of $10 \%$ in the marginal herds and $50 \%$ in organized farms, and the socio-economic impact of the disease was estimated to run over Rs. 500 crores annually. In Punjab, overall 17.7\% prevalence of brucellosis was reported in cattle and buffaloes $[1,2]$. It causes heavy economic loss to the animal industry through delayed conception, late-term abortions and retention of placenta and temporary or permanent infertility [3] in females and orchitis and epididymitis in males, with excretion of organisms in semen, uterine discharges and in milk [4]. Once infected, the animal may continue to shed bacteria and remains a source of infection to others for long period[2]. Sometimes the vaccinated animals may also suffer from Brucellosis due to inadequate immunity induced by the vaccine [5]. Phage therapy may be effective in chronic carriers infected with antibiotic resistant bacteria. However, little data are available in the published literature on the effects of phage therapy on host immune response to natural infection of Brucellosis in cattle. The present study was, therefore, undertaken to explore this aspect of phage therapy of bovine brucellosis.

\section{Materials and Methods \\ Ethical approval}

All the experimental protocols performed on cattle were approved by the Institutional Animal Ethics Committee (IAEC). Animals were kept in IAEC approved facilities and received feed and water ad libitum.

\section{Infected cattle}

Six naturally infected brucellosis positive adult cattle, which had been vaccinated during calf hood with B. abortus_strain 19 vaccine 
(Bruvax; Indian Immunologicals) maintained at the University Dairy Farm were included in the study.

\section{Preparation of phage for therapy}

Phage preparation was produced employing standardized optimum conditions. The eluted phage preparation in SM diluent was purified using $0.22 \mu \mathrm{m}$ PVDF filter before preparing the phage for the therapy. The phage count in the preparation was made to the required dose of $10^{8} \mathrm{pfu} / \mathrm{ml}$ and stored at $4^{\circ} \mathrm{C}$ until use.

\section{Sterility testing of phage preparation}

Sterility test was carried out as per the Indian Pharmacopoeia Section 2.2.11. A loopful of the phage preparation was suspended in $5 \mathrm{ml} \mathrm{BHI} \mathrm{broth} \mathrm{as} \mathrm{well} \mathrm{as} \mathrm{streaked} \mathrm{on} \mathrm{BHI} \mathrm{and} \mathrm{blood} \mathrm{agar} \mathrm{plates}$ followed by incubation at $37^{\circ} \mathrm{C}$. The broth and the plates were examined upto 48 hours for any microbial growth.

\section{Safety test of phage in mice}

Safety test was conducted by injecting $0.5 \mathrm{ml}$ of phage preparation through subcutaneous, intramuscular and intraperitoneal route into each of the three mice. The mice were observed for any untoward reactions or mortality till $7^{\text {th }}$ day of inoculation.

\section{Treatment trials in cattle}

Treatment trials of the phage preparation were carried out on naturally Brucellosis infected Holstein Friesian crossbred adult cattle at the University Dairy Farm, GADVASU, Ludhiana. Six Brucellosis positive adult cattle were treated with $2 \mathrm{ml}$ of $10^{8} \mathrm{pfu} /$ ml_brucellaphage preparation through subcutaneous route.

\section{Collection of blood}

Blood samples were collected from cattle through jugular vein at $0,30,45,60,75$ and 90 days post treatment. Anti-coagulated blood was collected for separating leukocytes while sera were separated from clotted blood and stored at $-20^{\circ} \mathrm{C}$ until further use for studying the immune response of the treated animals.

\section{Analysis of immune responses}

\section{Estimation of total protein levels in serum samples}

The total protein content in serum samples of phage treated cattle at $0,30,45,60,75$ and 90 days post treatment were determined by using Vitros TP slides and the Vitros DTSC (Johnson and Johnson Company) instrument.

\section{Estimation of total globulin levels in serum samples}

Total globulin levels in the serum samples of treated cattle at 0 , $30,45,60,75$ and 90 days post treatment were estimated by subtracting albumin content from the total protein level determined by using Vitros TP slides, Vitros ALB DT slides and the Vitros DTSC (Johnson and Johnson Company) instrument.

\section{Estimation of antibody titers}

Titers of anti-Brucella antibodies in the serum samples of phage treated cattle at $0,30,45,60,75$ and 90 days post treatment were estimated by Standard Tube Agglutination Test (STAT), Microtiter plate Agglutination Test (MAT), Indirect Hemagglutination Assay (IHA) and Enzyme-Linked ImmunoSorbent Assay (ELISA). The methods followed have been described earlier [5].

Estimation of total leukocyte counts (TLC) in the blood of treated cattle

Levels of total leukocytes in blood samples of phage treated Brucellosis affected cattle at $0,30,45,60,75$ and 90 days post treatment were determined. Approximately $20 \mu \mathrm{l}$ of blood from treated cattle was mixed with $300 \mu \mathrm{l}$ of WBC diluting fluid (BTL Research Lab, India) and kept for 10 minutes undisturbed. One drop of the diluted blood was loaded into Neubeauer's counting slide and a cover slip was put over it. The number of cells in the WBC counting chamber was counted under a microscope.

Estimation of differential leukocyte counts (DLC) in the blood of treated cattle

Levels of leukocyte subsets in blood samples of phage treated Brucellosis affected cattle were determined at 0, 30, 45, 60, 75 and 90 days post treatment. Blood smear from treated cattle was prepared on a clean microscopic slide and the slide was air dried. Fixation was done by immersing the slide in methanol for around 5 minutes. The slide was flooded with Giemsa stain and kept for 10 minutes. Afterwards it was washed in running water and the slide was kept for drying. The slide was observed under a microscope and the total numbers of cells were counted upto 100 cells.

\section{Statistical analysis of data}

Data were statistically analyzed by analysis of variance and $t$ test.

\section{Results and Discussion}

Bacteriophages are viruses that infect and multiply inside the bacteria. Bacteriophages that infect the Brucella species are called Brucellaphages. Use of lytic bacteriophages to treat Brucellosis can be a cheap and effective alternative to antibiotics for control of the disease. Lytic phages grow in the viable bacterial cells, reproduce within and lyse the bacteria without damaging the normal flora [6]. The self-replicating and self-limiting nature of lytic bacteriophages make them a safe alternative to antibiotics for treatment of bacterial diseases of animals [6]. Our present study was undertaken 
to investigate the effect of brucellaphage therapy on immune responses in cattle naturally infected with Brucella abortus.

A broad acting phage lytic to Brucella organisms isolated in our laboratory was used for the present study. Brucella abortus strain 19 organism was used for the revival and propagation of phage. The plates having plaque formation were confirmed for the presence of phage by secondary streaking. The brucellaphage lysed Brucella abortus strain 19, Brucella abortus strain 99 and Brucella melitensis (procured from IVRI, Izatnagar) but did not lyse any of the heterologous species tested viz. Staphylococcus aureus, Salmonella species, Escherichia coli and Pasteurella multocida.

The total serum protein concentrations $(\mathrm{g} / \mathrm{dl})$ in phage treated cattle suffering from Brucellosis (treated cattle) increased from 5.05 to 8.15 in 45 days and then slowly declined to 6.39 by 90 days post treatment (Table 1 and figure 1). The increase in total serum proteins from $0 \mathrm{D}$ to $45 \mathrm{D}, 60 \mathrm{D}$ and $75 \mathrm{D}$ and from $30 \mathrm{D}$ to $45 \mathrm{D}$ followed by a decrease from 45D to $90 \mathrm{D}$, respectively was very significant $(\mathrm{p}<0.01)$. The increase in total serum proteins from $0 \mathrm{D}$ to 30D and 90D followed by a decrease from 45D to 75D was significant $(\mathrm{p}<0.05)$.

The serum globulin levels (g/dl) in treated cattle rose from 2.1 to 4.86 in one and a half month and thereafter gradually declined to 3.06 by 3 months post treatment (Table 2 and figure 1). The increase in serum globulin level from 0D to 45D and 60D was very significant $(p<0.01)$. The increase in serum globulin from $30 \mathrm{D}$ to $45 \mathrm{D}$ and decrease from 45D to 90D were significant ( $\mathrm{p}<0.05$ ).

Titers of anti-Brucella antibodies as determined by STAT (STAT titers) increased gradually from $1.953 \pm 0.29$ to $2.755 \pm 0.12$ in one and a half month and thereafter slowly declined to $2.153 \pm 0.44$ by $90^{\text {th }}$ day post therapy (Table 3 and figure 2 ). The rise in STAT titers from $0 \mathrm{D}$ to $45 \mathrm{D}$ and $60 \mathrm{D}$ was very significant $(\mathrm{p}<0.01$ ) The decline from $45 \mathrm{D}$ to $90 \mathrm{D}$ was significant $(\mathrm{p}<0.05)$. MAT titers increased gradually from $1.802 \pm 0.24$ to $3.759 \pm 0.44$ by 45 day and then declined slowly to $2.404 \pm 0.80$ three months post treatment (Table 4 and figure 2). The rise in MAT titers from 0D to 45D and 60D, along with decline from 45D to 90D was very significant $(\mathrm{p}<0.01)$. The rise in titer from $30 \mathrm{D}$ to $45 \mathrm{D}$ was significant $(\mathrm{p}<0.05$ ). IHA titers (Table 5 and figure 2) increased from $2.053 \pm 0.31$ to $3.859 \pm$ 0.36 by 45 day along with a gradual decline to $2.856 \pm 0.94$ after 3 months of therapy. The rise in IHA titers from 0D to $45 \mathrm{D}$ and $60 \mathrm{D}$ was very significant $(\mathrm{p}<0.01)$ and the rise from $0 \mathrm{D}$ to $75 \mathrm{D}$ was significant $(\mathrm{p}<0.05)$. ELISA titers rose from $1.122 \pm 0.44$ to $1.361 \pm$ 0.05 at one month along with a gradual decline to $0.803 \pm 0.17$ at 90 day (Table 6 and figure 2). The decline in ELISA titers from 30D

\begin{tabular}{|l|c|c|c|c|c|c|}
\hline Sl. No. & 0 D & 30D & 45 D & 60 D & 75 D & 90 D \\
\hline 1 & 5.6 & 7.3 & 7.6 & 7.5 & 6.6 & 6.6 \\
\hline 2 & 5.8 & 6.7 & 6.7 & 6.8 & 6.2 & 5.6 \\
\hline 3 & 6.0 & 6.9 & 9.0 & 8.0 & 7.1 & 6.7 \\
\hline 4 & 3.9 & 6.2 & 9.3 & 8.1 & 7.7 & 7.1 \\
\hline 5 & 4.0 & 5.8 & 8.2 & 7.5 & 6.7 & 5.8 \\
\hline 6 & 5.0 & 6.2 & 8.1 & 7.2 & 7.1 & 6.6 \\
\hline \multirow{2}{*}{ Mean \pm SD } & $\begin{array}{c}5.05 \pm \\
0.91\end{array}$ & $\begin{array}{c}6.51 \pm \\
0.54\end{array}$ & $\begin{array}{c}8.15 \pm \\
0.94\end{array}$ & $\begin{array}{c}7.51 \pm \\
0.48\end{array}$ & $\begin{array}{c}6.89 \pm \\
0.51\end{array}$ & $\begin{array}{c}6.39 \pm \\
0.57\end{array}$ \\
\hline
\end{tabular}

Table 1: Total serum protein levels in Brucellosis affected cattle after phage therapy.

\begin{tabular}{|l|c|c|c|c|c|c|}
\hline Sl. No. & 0 D & 30D & 45 D & 60 D & 75 D & 90 D \\
\hline 1 & 2.1 & 2.3 & 4.7 & 4.4 & 4.0 & 3.8 \\
\hline 2 & 2.4 & 2.8 & 3.7 & 3.7 & 3.0 & 2.6 \\
\hline 3 & 3.0 & 3.1 & 6.6 & 4.5 & 3.8 & 3.8 \\
\hline 4 & 2.4 & 4.9 & 6.0 & 5.0 & 4.0 & 3.6 \\
\hline 5 & 1.0 & 1.7 & 4.4 & 3.5 & 3.2 & 2.0 \\
\hline 6 & 2.8 & 3.6 & 3.8 & 3.7 & 3.3 & 2.6 \\
\hline \multirow{2}{*}{ Mean \pm SD } & $2.1 \pm 0.7$ & $\begin{array}{c}3.06 \pm \\
1.01\end{array}$ & $\begin{array}{c}4.86 \pm \\
1.18\end{array}$ & $\begin{array}{c}4.13 \pm \\
0.58\end{array}$ & $\begin{array}{c}3.55 \pm \\
0.43\end{array}$ & $\begin{array}{c}3.06 \pm \\
0.76\end{array}$ \\
\hline
\end{tabular}

Table 2: Serum globulin levels in Brucellosis affected cattle after phage therapy.

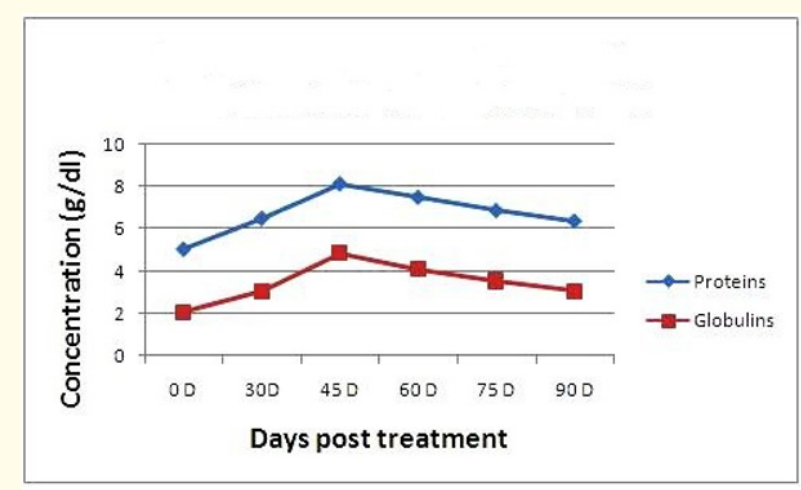

Figure 1: Serum proteins and globulin levels in Brucellosis affected cows treated with phage.

to $60 \mathrm{D}, 75 \mathrm{D}$, and $90 \mathrm{D}$, respectively was very significant $(\mathrm{p}<0.01)$. The decline in titers from $0 \mathrm{D}$ to $60 \mathrm{D}$ and $75 \mathrm{D}$ and from $45 \mathrm{D}$ to $60 \mathrm{D}$ and 75D was significant $(\mathrm{p}<0.05)$.

Total leukocyte count in the peripheral blood of Brucellosis affected cattle increased from 5766.66 to 8150 by one month followed by a decline to 6883.33 till 60 day and then gradual increase 


\begin{tabular}{|l|c|c|c|c|c|c|}
\hline Sl. No. & 0 D & 30D & 45 D & 60 D & 75 D & 90 D \\
\hline 1 & 2.204 & 2.505 & 2.806 & 2.806 & 2.806 & 2.806 \\
\hline 2 & 1.602 & 2.204 & 2.806 & 2.806 & 1.903 & 1.903 \\
\hline 3 & 1.602 & 2.505 & 2.806 & 2.204 & 1.903 & 1.602 \\
\hline 4 & 2.204 & 2.505 & 2.806 & 2.806 & 2.806 & 2.204 \\
\hline 5 & 1.903 & 2.204 & 2.505 & 2.505 & 2.505 & 2.505 \\
\hline 6 & 2.204 & 2.505 & 2.806 & 2.505 & 2.204 & 1.903 \\
\hline Mean \pm SD & $\begin{array}{c}1.953 \pm \\
0.29\end{array}$ & $\begin{array}{c}2.404 \pm \\
0.15\end{array}$ & $\begin{array}{c}2.755 \pm \\
0.12\end{array}$ & $\begin{array}{c}2.605 \pm \\
0.24\end{array}$ & $\begin{array}{c}2.354 \pm \\
0.41\end{array}$ & $\begin{array}{c}2.153 \\
\pm 0.44\end{array}$ \\
\hline
\end{tabular}

Table 3: Antibody titers by standard tube agglutination test (STAT) in brucellosis affected cattle after treatment with phage.

\begin{tabular}{|l|c|c|c|c|c|c|}
\hline Sl. No. & 0 D & 30D & 45 D & 60 D & 75 D & 90 D \\
\hline 1 & 1.602 & 2.204 & 3.408 & 3.408 & 3.408 & 3.408 \\
\hline 2 & 1.903 & 3.107 & 3.709 & 3.709 & 1.903 & 1.903 \\
\hline 3 & 1.602 & 1.903 & 4.311 & 3.408 & 2.806 & 2.204 \\
\hline 4 & 1.602 & 1.903 & 3.408 & 3.408 & 3.408 & 1.903 \\
\hline 5 & 1.903 & 2.204 & 3.408 & 3.408 & 3.408 & 3.408 \\
\hline 6 & 2.204 & 3.709 & 4.311 & 2.204 & 1.903 & 1.602 \\
\hline Mean \pm SD & $1.802 \pm$ & $2.505 \pm$ & $3.759 \pm$ & $3.257 \pm$ & $2.806 \pm$ \\
& 0.24 & 0.73 & 0.44 & 0.52 & 0.73 & $0.404 \pm$ \\
\hline
\end{tabular}

Table 4: Antibody titers by microtitre plate agglutination test (MAT) in brucellosis affected cattle after treatment with phage.

\begin{tabular}{|l|c|c|c|c|c|c|}
\hline Sl.No. & 0 D & 30D & 45 D & 60 D & 75 D & 90 D \\
\hline 1 & 2.505 & 3.107 & 3.709 & 3.709 & 3.709 & 3.709 \\
\hline 2 & 1.903 & 3.107 & 3.408 & 2.505 & 2.204 & 1.903 \\
\hline 3 & 1.602 & 1.903 & 3.709 & 3.408 & 2.505 & 2.204 \\
\hline 4 & 1.903 & 2.505 & 4.311 & 4.311 & 4.311 & 3.709 \\
\hline 5 & 2.204 & 3.408 & 3.709 & 3.709 & 3.709 & 3.709 \\
\hline 6 & 2.204 & 3.709 & 4.311 & 4.311 & 3.107 & 1.903 \\
\hline Mean \pm SD & $\begin{array}{c}2.053 \pm \\
0.31\end{array}$ & $\begin{array}{c}2.956 \pm \\
0.65\end{array}$ & $\begin{array}{c}3.859 \pm \\
0.36\end{array}$ & $\begin{array}{c}3.658 \pm \\
0.67\end{array}$ & $\begin{array}{c}3.257 \pm \\
0.80\end{array}$ & $\begin{array}{c}2.856 \pm \\
0.94\end{array}$ \\
\hline
\end{tabular}

Table 5: Antibody titers by indirect haemagglutination test (IHA) test in brucellosis affected cattle treated with phage.

to 8183.33 by 3 months after initiation of phage therapy (Table 7 and figure 3). Blood lymphocyte levels (percentage) reduced considerably from 54.5 to 35.33 by 1 month and then rose to 60 by 45 day, followed by slight decline reaching 54.83 by 90 day post treatment (Table 8 and figure 4). Monocytes increased from 2.83 to 3.16 by 30 day and then declined to 1.66 by 45 day, maintained similar level till 75 day and then reached 2.16 by day 90 (Table

\begin{tabular}{|l|c|c|c|c|c|c|}
\hline Sl. No. & 0 D & 30D & 45 D & 60 D & 75 D & 90 D \\
\hline 1 & 1.453 & 1.434 & 1.331 & 0.784 & 0.754 & 1.100 \\
\hline 2 & 0.610 & 1.292 & 1.245 & 0.704 & 0.500 & 0.756 \\
\hline 3 & 1.293 & 1.422 & 1.176 & 0.671 & 0.753 & 0.780 \\
\hline 4 & 0.496 & 1.303 & 0.691 & 0.511 & 0.574 & 0.562 \\
\hline 5 & 1.408 & 1.347 & 1.001 & 0.685 & 0.709 & 0.788 \\
\hline 6 & 1.473 & 1.367 & 1.174 & 0.733 & 0.822 & 0.832 \\
\hline Mean \pm SD & $\begin{array}{c}1.122 \pm \\
0.44\end{array}$ & $\begin{array}{c}1.361 \pm \\
0.05\end{array}$ & $\begin{array}{c}1.103 \pm \\
0.20\end{array}$ & $\begin{array}{c}0.681 \pm \\
0.09\end{array}$ & $\begin{array}{c}0.685 \pm \\
0.12\end{array}$ & $\begin{array}{c}0.803 \pm \\
0.17\end{array}$ \\
\hline
\end{tabular}

Table 6: Antibody titers (OD values) by ELISA in Brucellosis affected cattle treated with phage.

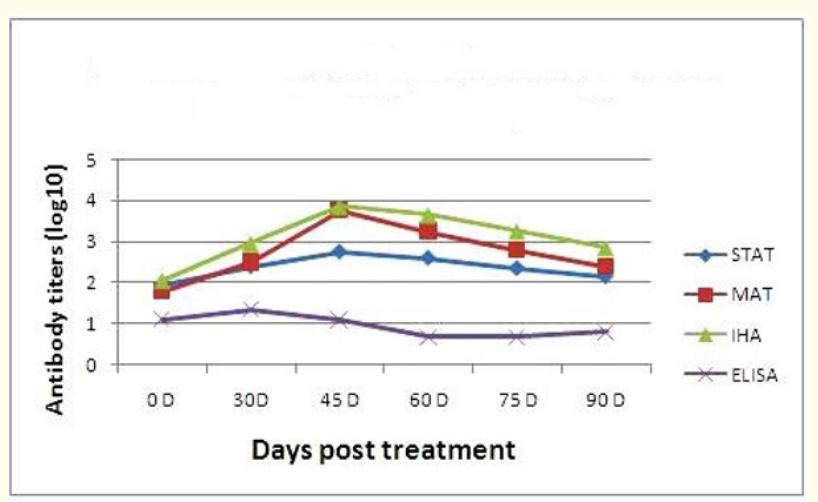

Figure 2: Antibody titers in Brucellosis affected cows after phage therapy.

\begin{tabular}{|c|c|c|c|c|c|c|}
\hline Sl. No. & 0 D & 30D & 45 D & $60 \mathrm{D}$ & 75 D & $90 \mathrm{D}$ \\
\hline 1 & 5900 & 7500 & 5900 & 6100 & 5200 & 9200 \\
\hline 2 & 4800 & 9200 & 8200 & 5200 & 6800 & 8100 \\
\hline 3 & 6200 & 10200 & 7800 & 9800 & 7600 & 10200 \\
\hline 4 & 6900 & 6500 & 5900 & 5800 & 9900 & 6500 \\
\hline 5 & 5700 & 8300 & 9400 & 6900 & 8400 & 7300 \\
\hline 6 & 5100 & 7200 & 8500 & 7500 & 8900 & 7800 \\
\hline $\begin{array}{l}\text { Mean } \\
\pm \text { SD }\end{array}$ & $\begin{array}{c}5766.66 \pm \\
758.06\end{array}$ & $\begin{array}{c}8150 \pm \\
1369.30\end{array}$ & $\begin{array}{c}7616.66 \pm \\
1430.26\end{array}$ & $\begin{array}{c}6883.33 \pm \\
1643.67\end{array}$ & $\begin{array}{c}7800 \pm \\
1660.12\end{array}$ & $\begin{array}{c}8183.33 \\
\pm \\
1331.79\end{array}$ \\
\hline
\end{tabular}

Table 7: Total blood leukocyte count (TLC) in Brucellosis affected animals treated with phage.

9 and figure 4). Neutrophil counts did not vary considerably from 39.83 at 0 day to 38.33 at day 75 and 40.83 at day 90 (Table10 and figure 4). The decrease in the levels of lymphocytes from 0D to 30D followed by increase from 30D to 45D, 60D, 75D and 90D was very 


\begin{tabular}{|l|c|c|c|c|c|c|}
\hline Sl. No. & 0 D & 30D & 45 D & 60 D & 75 D & 90 D \\
\hline 1 & 66 & 50 & 55 & 56 & 50 & 51 \\
\hline 2 & 54 & 30 & 62 & 58 & 58 & 50 \\
\hline 3 & 55 & 24 & 64 & 65 & 49 & 62 \\
\hline 4 & 50 & 44 & 53 & 63 & 65 & 55 \\
\hline 5 & 46 & 34 & 68 & 60 & 60 & 53 \\
\hline 6 & 56 & 30 & 58 & 57 & 58 & 58 \\
\hline Mean \pm SD & $54.5 \pm$ & $35.33 \pm$ & $60 \pm$ & $59.83 \pm$ & $56.66 \pm$ & $54.83 \pm$ \\
& 6.74 & 9.77 & 5.69 & 3.54 & 6.12 & 4.53 \\
\hline
\end{tabular}

Table 8: Blood lymphocyte counts in Brucellosis affected animals treated with phage.

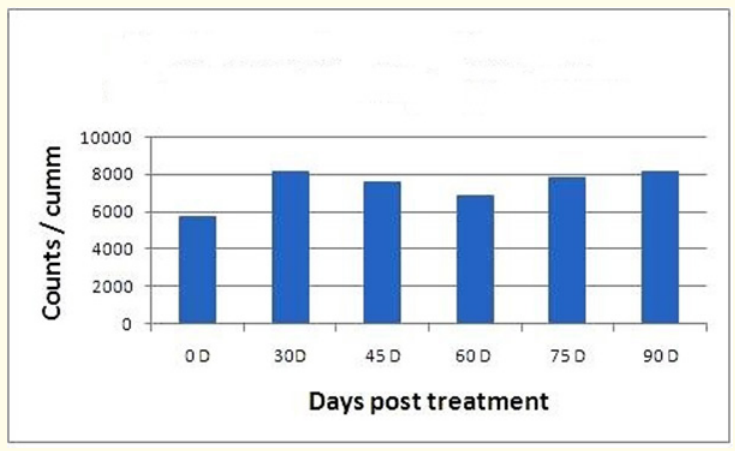

Figure 3: Total blood leukocyte counts in Brucellosis affected animals treated with phage.

\begin{tabular}{|l|c|c|c|c|c|c|}
\hline Sl. No. & 0 D & 30D & 45 D & 60 D & 75 D & 90 D \\
\hline 1 & 1 & 3 & 2 & 2 & 1 & 3 \\
\hline 2 & 4 & 4 & 3 & 4 & 2 & 3 \\
\hline 3 & 4 & 2 & 1 & 1 & 3 & 2 \\
\hline 4 & 4 & 4 & 1 & 1 & 2 & 1 \\
\hline 5 & 1 & 3 & 2 & 1 & 4 & 2 \\
\hline 6 & 3 & 3 & 1 & 1 & 2 & 2 \\
\hline Mean \pm SD & $2.83 \pm$ & $3.16 \pm$ & $1.66 \pm$ & $1.66 \pm$ & $1.66 \pm$ & $2.16 \pm$ \\
& 1.47 & 0.75 & 0.81 & 1.21 & 1.21 & 0.75 \\
\hline
\end{tabular}

Table 9: Blood monocyte counts in Brucellosis affected animals treated with phage.

significant $(\mathrm{p}<0.01)$. However, the levels of leukocytes, monocytes and neutrophils did not differ significantly among themselves during the period of 90 days after treatment with the phage.

\section{Conclusion}

Our present study indicates that phage therapy in Brucellosis stimulates immune responses in cattle initially for about one and

\begin{tabular}{|l|c|c|c|c|c|c|}
\hline Sl. No. & 0 D & 30D & 45 D & 60 D & 75 D & 90 D \\
\hline 1 & 31 & 50 & 42 & 40 & 48 & 44 \\
\hline 2 & 39 & 30 & 33 & 36 & 38 & 44 \\
\hline 3 & 36 & 24 & 33 & 31 & 46 & 33 \\
\hline 4 & 43 & 44 & 44 & 33 & 30 & 42 \\
\hline 5 & 50 & 34 & 28 & 38 & 32 & 43 \\
\hline 6 & 40 & 30 & 39 & 40 & 36 & 39 \\
\hline Mean \pm SD & $\begin{array}{c}39.83 \pm \\
6.43\end{array}$ & $\begin{array}{c}35.33 \pm \\
9.77\end{array}$ & $\begin{array}{c}36.5 \pm \\
6.15\end{array}$ & $\begin{array}{c}36.33 \pm \\
3.72\end{array}$ & $\begin{array}{c}38.33 \pm \\
7.31\end{array}$ & $\begin{array}{c}40.83 \pm \\
4.26\end{array}$ \\
\hline
\end{tabular}

Table 10: Blood neutrophil counts in brucellosis affected animals treated with phage.

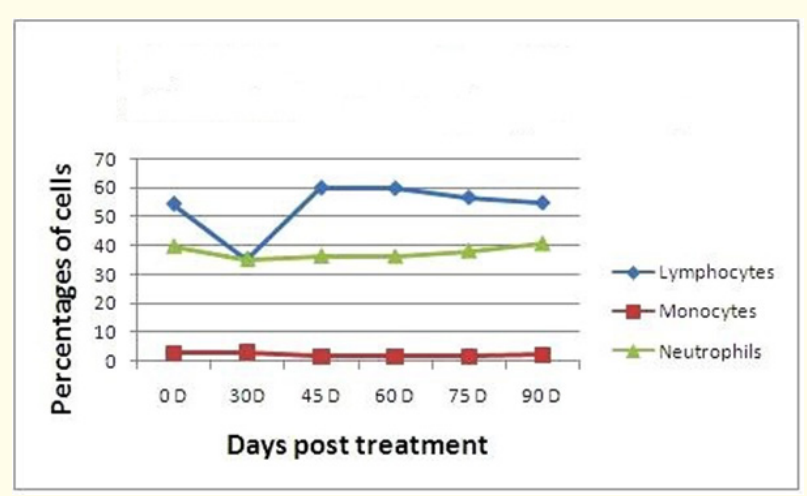

Figure 4: Levels of different subsets of leukocytes in Brucellosis affected animals treated with phage.

a half month which decline slowly after 45 days of initiation of therapy.

\section{Bibliography}

1. Jain U., et al. "Outbreak of brucellosis in buffaloes aborted in z village Mahuan, district Mainpuri, UP, India - A case report". Veterinary World 6.1 (2013): 51-52.

2. Pandeya Y R., et al. "Seroprevalence of brucellosis in different animal species of Kailali district Nepal". International Journal of Infection and Microbiology 2.1 (2013): 22-25.

3. Kollannur JD., et al. "Epidemiology and economics of brucellosis in animals and its zoonotic significance". Proceedings of XIII International Congress in Animal Hygiene. International Society for Animal Hygiene (2007): 466-468.

4. Godfroid J., et al. "Brucellosis in terrestrial wildlife". Revue Scientifique et Technique (International Office of Epizootics) 32.1 (2013): 27-42. 
5. Mohan A., et al. "A comparison of titers of anti-Brucella antibodies of naturally infected and healthy vaccinated cattle by standard tube agglutination test, microtiter plate agglutination test, indirect hemagglutination assay, and indirect enzyme-linked immunosorbent assay". Veterinary World 9.7 (2016): 717-722.

6. Haq I U., et al. "Bacteriophages and their implications on future biotechnology: A review". Virology Journal 9 (2012): 9.

\section{Assets from publication with us}

- Prompt Acknowledgement after receiving the article

- Thorough Double blinded peer review

- Rapid Publication

- Issue of Publication Certificate

- High visibility of your Published work

Website: https://www.actascientific.com/

Submit Article: https://www.actascientific.com/submission.php Email us: editor@actascientific.com

Contact us: +919182824667 